\title{
JUAN RULFO: CUESTIÓN DE FECHAS
}

\author{
POR \\ Gustavo Fares \\ Lynchburg College
}

En el número 164-165 del volumen LIX de la Revista Iberoamericana aparecieron dos notas acerca de la más reciente edición crítica de la obra del escritor mexicano Juan Rulfo en la colección Archivos. "Un nuevo asedio a la obra de Juan Rulfo" de Warren Miendhardt ponía de relieve algunas de las imprecisiones en la edición citada, caracterizándola como "un libro destinado a causar múltiples dolores de cabeza para críticos, estudiosos y bibliógrafos" (741). El comentario de Miendhardt era, asimismo, exhaustivo e informador, ya que detallaba sus observaciones de acuerdo a cada una de las secciones que componen la obra editada en la colección Archivos. El segundo artículo, en el mismo número de la Revista, aparecía en la sección de reseñas, de la autoría de José Carlos González Boixo, una autoridad en lo que hace a la obra del escritor mexicano. Su reseña era de tono general y sumamente positiva, destacando el "eminente esfuerzo" (812) que la citada edición había supuesto. Ninguno de los comentarios mencionados, sin embargo, ponía de relieve una fecha, lo suficientemente importante como para que, a estas alturas de la investigación y del debate acerca de Rulfo y de su lugar en las letras latinoamericanas, se diera por sentada. Me refiero a la fecha de su nacimiento. En la sección "Cronología" de la citada edición crítica la fecha del nacimiento de Rulfo aparece en el año 1918 (407). Y es aquí que me interesa destacar que tal fecha es errónea, al menos de acuerdo al acta de nacimiento del escritor, que se encuentra en la ciudad de Sayula, y que establece que como año de su nacimiento el de 1917.

Caí en la cuenta de este error después de leer la cronología de la vida de Rulfo, y de compararla con una que había confeccionado, no hace mucho. En ella la fecha de nacimiento de Rulfo era, efectivamente, la de 1917 , y al revisar mis papeles me di cuenta del error en la edición crítica. Cuando me refiero a "mis papeles" en realidad hablo de un pequeño libro que me fue obsequiado en uno de mis viajes al lugar rulfiano. Viajando por Jalisco durante 1987, me dirigí a la ciudad de Sayula, aquélla que aparece en Pedro Páramo, la misma en donde, a la hora del atardecer, se escuchaban las risas de los niños y se veían las aves llenando el cielo, aquélla en donde el sol de la tarde rebotaba de las paredes de las casas, aquélla a donde Juan Preciado va antes de comenzar su descenso a Comala. Y en Sayula tuve la fortuna de conocer a don Federico Munguía Cárdenas, dueño de un comercio en el centro de la ciudad y poseedor, además, de una hospitalidad proverbial. Con él recorrí los pueblos de la zona rulfiana, con él comí desgranando anécdotas acerca de Juan Rulfo, de su familia y amigos. Él, don Federico, me dió un libro en el cual se encontraban una 
selección de sus investigaciones acerca de la vida de Rulfo, investigaciones en las que, por cuenta propia, se había enfrascado por años. En sus Antecedentes y datos biográficos de Juan Rulfo (Guadalajara: UNED, 1987) se detalla minuciosamente la fecha de nacimiento del escritor. En sus páginas se encuentra la fotocopia del acta de nacimiento y del acta de bautismo de Rulfo (que acompaño con estas líneas) y en donde queda asentada, sin duda, la fecha de su nacimiento. La transcripción del acta de nacimiento dice así:

En Sayula a las 11 1/2 once y media de la mañana del día 24 veinticuatro de mayo de 1917 mil novecientos diecisiete, ante mi Teniente Coronel Francisco Valdes, Presidente Municipal y Encargado del Registro Civil, compareció el Ciudadano J. Nepomuceno Pérez Rulfo, casado, agricultor de 28 veintiocho años de edad, originario y vecino de esta ciudad expuso: que en la casa número 32 treinta y dos de la calle de Francisco y Madero nació en 3er tercer lugar y a las 5 de la mañana del día 16 dieciséis del actual el niño que presenta vivo a quien puso por nombre Juan Nepomuceno Pérez Vizcaíno, é hijo legítimo del exponente y de su esposa María Vizcaíno Arias de 20 veinte años de edad. Son abuelos paternos: Severiano Pérez Jiménez y María Rulfo y maternos Carlos Vizcaíno y Tuburcia Arias. Fueron testigos de este acto los ciudadanos Gerónimo Celis, casado de 41 cuarenta y un años y Luis Ochoa Rodríguez, Soltero ambos empleados y vecinos de aquí y sin parentesco con el nacido. Leida que les fué la presente manifestaron su conformidad y firmaron;- G. Celis. - F. Valdez.- Juan N. Pérez Rulfo.- L. Ochoa (FIRMAS) (Munguía Cárdenas 18-19).

Por si queda alguna duda acerca del asiento en el registro de la ciudad ante la autoridad pública, el acta de bautismo certifica que el año de 1917 no es una equivocación. El acta se encuentra en la página 45 reverso del libro número 69 de bautismos de la parroquia de Sayula, y dice:

Acta Núm. 166. Carlos Juan Nepomuceno Pérez nacido en esta ciudad.-En la Yglesia (sic) parroquial de Sayula, a los (sic) once días del mes de junio de mil novecientos diecisiete, el Presbítero Román Aguilar Cura interino de esta parroquia, bauticé solemnemente y puse el Santo oleo y Sagrado Crisma a un niño nacido en esta ciudad, el día dieciseis del próximo pasado a las cinco de la mañana, a quien puse por nombre CARLOS JUANNEPOMUCENO, hijo legítimo de Juan Nepomuceno Pérez Rulfo y de María Vizcaíno Arias de Pérez Rulfo. Abuelos paternos Licenciado don Severiano Pérez Jiménez y doña María Rulfo de Pérez Jiménez. Abuelos maternos don carlos Vizcaíno y dona Tiburcia Arias. Fueron padrinos José de Jesús Pérez Rulfo y María Dolores Rulfo a quienes advertí su obligación y parentesco espiritual. Para constancia lo firmé.-ROMAN AGUILAR(Munguía Cárdenas 19).

A estas transcripciones, Federico Munguía Cárdenas acompaña la fotocopia de las actas mencionadas, por lo que no queda duda acerca del año de nacimiento de Juan Rulfo. Sabida es la costumbre del escritor de distorsionar hechos y fechas de su infancia y de su vida toda, así como otros datos que le pedían los críticos, una vez que se hizo famoso. Como si esa costumbre le permitiera tomar distancia con el mundo externo y encerrarse en sí mismo a escribir, o solamente a planear, historias. No es de extrañar, entonces, que hasta los editores de la obra de Rulfo en la colección Archivos, hayan sido víctima de los engaños del 
autor. Como guiñando el ojo, cómplice, se ha asegurado don Juan que, aún en esta edición de su obra que quiere ser definitiva, los datos que lo rodean se sigan discutiendo en notas como ésta. 
